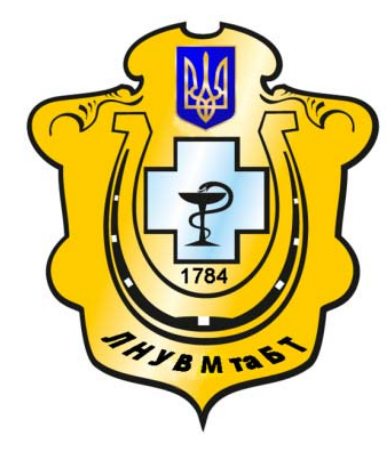

Науковий вісник Львівського національного університету ветеринарної медицини та біотехнологій імені С.3. Гжицького

Scientific Messenger of Lviv National University of Veterinary Medicine and Biotechnologies named after S.Z. Gzhytskyj

doi:10.15421/nvlvet7125

ISSN 2413-5550 print

ISSN 2518-1327 online

http://nvlvet.com.ua/

УДК 574.6:575

\title{
Теломерна теорія старіння клітини
}

\author{
О. Стахів, Н.П. Шемедюк \\ olya.stakhiv@gmail.com, natshem@bigmir.net
}

\begin{abstract}
Львівський національний університет ветеринарної медицини та біотехнологій імені С.3. Гжиџького, вул. Пекарська, 50, м. Львів, 79010, Україна
\end{abstract}

\begin{abstract}
Серед ряду теорій, шуо пояснюють явище старіння, велика увага сучасного наукового світу звернена у бік теломерної теорії. 3 чісї точки зору, старіння - ие результат пошкодження генетичного апарату. Процес запрограмований $i$ пов'язаний з експресією генів «старості» на певному етапі онтогенезу, які є причиною незворотних деструктивних змін у клітині. Підтверджує ию теорію наявність ліміту Хейфліка і теломерного лічильника поділу клітин. Ключовим моментом у теломерній теорії старіння є дослідження взаємозв'язку між типом клітин, наявністю у них функціонально активної теломерази і зупинкою клітинного ицилу. Механізм дії теломерази - добудовування нуклеотидних послідовностей у теломерних ділянках ДНК, які втрачаються з кожним поділом клітин. На даний час питання пошуку активаторів теломерази $\epsilon$ актуальним, про це свідчать наукові розробки, кількість яких збільшується з кожним роком.

Ключові слова: старіння, теломерна теорія, теломери, теломераза, проліферація клітин, клітинний цикл, ДНК, реплікаиія ДНК, недореплікаиія.
\end{abstract}

\section{Теломерная теория старения клетки}

\author{
О. Стахив, Н.П. Шемедюк \\ olya.stakhiv@gmail.com,natshem@bigmir.net
}

Львовский национальный университет ветеринарной медицины и биотехнологий имени С.3. Гжиџкого, ул. Пекарская, 50, г. Львов, 79010, Украина

Среди ряда теорий, объясняющих явление старения, большое внимание современного научного мира обращено в сторону теломерной теории. С этой точки зрения, старение - это результат повреждения генетического аппарата, накопления ошибок в системе генетической информачии. Прочесс запрограммирован и связан с экспрессией генов «старости» на определенном этапе онтогенеза, которые являются причиной деградирования клетки. Подтверждает эту теорию наличие лимита Хейфлика и теломерного счетчика деления клеток. Ключевым моментом в теломерной теории старения является исследование взаимосвязи между типом клеток, наличием в них функиионально активной теломеразы и остановкой клеточного иикла. Механизм действия теломеразы - вставка нуклеотидных последовательностей в теломерные участки ДНК, которые теряются с каждым делением клетки. В настоящее время вопрос поиска активаторов теломеразы является актуальным, об этом свидетельствуют научные разработки, количество которых увеличивается с каждым годом.

Ключевые слова: старение, теломерная теория, теломеры, теломераза, пролиферация клетки, клеточный цикл, ДНК, репликащия ДНК, недорепликация.

\section{Telomer theory of aging of cell}

\author{
O. Stakhiv, N. Shemediuk \\ olya.stakhiv@gmail.com, natshem@bigmir.net
}

Lviv National University of Veterinary Medicine and Biotechnologies named after S.Z. Gzhytskyj,

Citation:

Stakhiv, O., Shemediuk, N. (2016). Telomer theory of aging of cell. Scientific Messenger LNUVMBT named after S.Z. Gzhytskyj, 18, 3(71), 109-111. 


\section{Pekarska Str., 50, Lviv, 79010, Ukraine}

Among the row of theories that explain the phenomen on of aging, the large attention of the modern scientific world is turn to ed a side of telomer theory. From this point of view, aging is a result of damage to the genetic apparat. A process is programed and related to expression of genes of old «age» on the certain stage of ontogenesis, that are reason destructive changes in a cell. The presence Heynflick's limit and telomer meter of division of cell sustains this theory. The telomere theory of aging has research of intercommunication of a key moments between the type of cells, presence in a functionally active telomeraza and by stopping of cellular cycle. The telomeraza mechanism of action is building of sequences of nucleotide in the areas of DNA, that is lost with every division of cells. Disruption of the body is a result of the telomere shortening after every cycle of DNA replication. It doesn't depend on time, but from the amount of replication of DNA and it can be replicometr, that determines the amount of cell divisions. After the achievement critical length of telomeric DNA segments a cellular cycle is stopped in $G_{1}$ or $G_{2} / M$ phases. Enzyme contains TERT (telomerase reverse transcriptase), TER (telomerase RNA). An important catalytic domen which inherent reverse transcriptases, domen of joining TER, DNA-substrate, are part of TERT. On this time question of searching activators of telomeraza is actual, sciens are interested in it so that number of advanced studies are increase every year.

Key words: aging, telomer theory, telomers, telomeraza, proliferation of cell, cellular cycle, DNA, replication of DNA, underreplication

\section{Вступ}

Організм - жива відкрита система, яка обмінюється із середовищем масою та енергією, функціонування його обгрунтовується законами термодинаміки. Здавалося б можна створити умови для вічного існування живого, та з часом така система характеризується збільшенням ентропії, наростає молекулярний хаос на фоні послаблення репаративних процесів організм старіє. Уникнути зростання ентропії не можливо. Старіння не можна вкласти лише у рамки фізичних законів, пояснення цьому явищу необхідно шукати у механізмах еволюції, молекулярногенетичних засадах.

Метою дослідження $є$ аналіз літературних даних щодо теломерної теорії старіння. У зв’язку з цим завданням статті $€$ коротка характеристика теломер, теломеразного комплексу і їх участь у процесі старіння.

Явище старіння виникло у ході еволюції живих організмів як фактор, що забезпечує генетичну мінливість популяції і виду. Також його можна розглядати як фізіологічний процес, що зменшує пристосувальні можливості організму, збільшує ймовірність виникнення вік-асоційованих захворювань та смерті. Основна теорія, яка пояснює явище старіння - теломерна теорія (Olovnikov, 1973; Harley et al., 2011).

У ХІХ ст. Л. Хейфлік довів: нормальні ембріональні клітини в сприятливих умовах старіють, а після близько 50-ти поділів гинуть. Вивчення теломер бере початок у 1971 р., коли О.М. Оловников дослідив, що ДНК-полімерази за кожного поділу клітини не здатні повністю відновлювати кінці хромосом у результаті чого утворюються недорепліковані ДНК. Вкорочення теломер - кінцевих гетерохроматинових ділянок хромосом, після кожного циклу реплікації ДНК призводить до порушення функцій організму (Danilevskaya et al.,1999). Воно залежить не від часу, а від кількості реплікацій ДНК і може бути реплікометром, який визначає кількість поділів клітини. 3 кожним циклом соматичні клітини втрачають від 50-ти до 200 нуклеотидів. Недореплікованим залишається 5'-кінець ДНК.

Після досягнення критичної довжини теломерної ділянки ДНК клітинний цикл зупиняється у фазах $\mathrm{G}_{1}$ або $\mathrm{G}_{2} / \mathrm{M}$. Вкорочення теломер сприймається білками $A T M$ та $p 53$ як сигнал про пошкодження ДНК, соматичні клітини переходять у стан проліферативного старіння і гинуть (Atadja et al., 1995; Karlseder et al., 1999; Pardue et al., 2005). Механізм кінцевої недореплікації пояснюється відсутністю в соматичних клітинах ферменту теломерази, яка функціонує в стовбурових і статевих клітинах.

Довгі теломери молодих клітин знаходяться у ділянці гетерохроматину, а ген-супрессор програми клітинного старіння, локалізований в субтеломерній ділянці. 3 вкороченням теломер субтеломерна ділянка ДНК переміщається у гетерохроматинову. Поява у гетерохроматиновій ДНК гена-супрессора призводить до його інактивації і запуску механізму клітинного старіння. Однак, причини, що запускають механізм вкорочення теломер ще вивчаються. Механізм недореплікації, можливо, є захисною реакцією організму, яка виникає у ході еволюції і $є$ попередженням онкологічної трансформації старіючих клітин (Berestjanaja and Grodzinskij, 2012).

Теломери - нуклеопротеїдні структури, розміщені на кінцях лінійних хромосом. Вони складаються із тисячі високо консервативних тандемних повторів TTAGGG. Теломери перешкоджають «злипанню» різних хромосом і забезпечують прикріплення кінців хромосом до ядерної мембрани. Теломери не містять кодуючих послідовностей, виконуючи функцію буферу, який захищає гени від втрати при кожному циклі реплікації ДНК. Також теломери беруть участь в стабілізації лінійних еукаріотичних хромосом шляхом елонгації і кепування (Rockmill and Roeder, 1998; Dynek and Smith, 2004).

Хромосоми без теломер можуть «злипатись» у наслідок чого виникають дицентричні, кільцеві хромосоми, транслокації, делеції. Частота появи дицентричних хромосом корелює із розміром теломер (Jager and Philippsen, 1989). Мутовані хромосоми здатні до деградації під час мітозу, їх пошкодження активує білок $p 53$, який запускає каскад реакцій, що спричиняють суперекспресію білка $p 21$. Даний білок зупиняє клітинний цикл у фазі $G_{l}$. Згадані білки можуть нейтралізувати мітогенну активність факторів росту (пояснення відсутності чутливості старіючих клітин до факторів росту). Суперекспресія р16 також може 
призводити до зупинки клітинного циклу у $G_{l}$. Сукупність наведених механізмів ініціює процес старіння, а вкорочення теломер - один з його першочинників (Karlseder et al., 1999; Baur et al., 2001).

У 2009 році Елізабет Блекберн, Керол Грейдер, Джек Шостак отримали Нобелівську премію $з$ фізіології та медицини «за відкриття механізмів захисту теломер хромосом і ферменту теломерази» (Berestjanaja and Grodzinskij, 2012).

Теломераза - рибонуклеопротеїдний комплекс, що подовжує теломеру хромосоми особливими TTAGGG послідовностями, тоді як комплементарний ланцюг добудовується ДНК-полімеразами. Коровий фермент містить теломеразну зворотню транскриптазу (TERT - telomerase reverse transcriptase), теломеразну РНК (TER - telomerase RNA). До складу TERT входить важливий каталітичний домен, властивий зворотнім транскриптазам, та домени, характерні лише їй: зв'язування TER, ДНК-субстрату, функціональної активності теломерази. Від інших РНК-залежнихДНК-полімераз теломеразу відрізняє те, що вона використовує фіксовану ділянку спеціальної теломеразної РНК як матрицю для подовження теломери (Zvereva et al., 2010; Berestjanaja and Grodzinskij, 2012). Допоміжні компоненти теломеразного комплексу забезпечують функціонування теломерази in vivo. Деякі з них необхідні для взаємодії теломерази та теломери у певний момент клітинного циклу, інші регулюють іï активність (Danilevskaya et al., 1999; Zvereva et al., 2010; Berestjanaja and Grodzinskij, 2012).

Відомо, що теломераза активна у $85 \%$ злоякісних пухлин, але iї активність не спостерігається у соматичних клітинах. Тому даний фермент вважають універсальною мішенню, яку можна використовувати при розробці протипухлинної терапії (Zvereva et al., 2010; Berestjanaja and Grodzinskij, 2012).

Отже, згідно теломерної теорії процес старіння залежить від довжини теломер та експресії ферменту теломерази. На основі сучаних даних розробляються фармакологічні препарати, наприклад, каліфорнійською компанією Geron було розроблено активатор теломерази $T A-65$. В основі препарату лежить речовина виділена 3 рослини Астрагал подібний (Astragalus propinquus), яка ефективно впливає на активацію теломерази (Zvereva et al., 2010; Berestjanaja and Grodzinskij, 2012).

\section{Висновки}

Неможливо однозначно пов'язати причини вікасоційованих захворювань з тією чи іншою теорією старіння. Позаяк найбільш грунтовне експериментальне підтвердження отримала теломерна теорія. Варто брати до уваги й інші деструктивні зміни генетичного апарату, кількість яких 3 віком лише збільшується (структурні дефекти, зменшення кількості 5метилцитозину, зниження активності ферментів репараціï), і враховувати їхнє значення у досліджуваному питанні, адже старіння клітини є багатостадійним, комплексним процесом, який супроводжується деградацією на молекулярному і біохімічному рівнях.

Перспективи подальших досліджень. На сьогоднішній день існує цілий напрям, що займається дослідженням природи старіння, в основі якого теломерна теорія. Учені намагаються зупинити вкорочення теломер шляхом безпечної активації теломерази у клітинах, де її активність вкрай низька чи відсутня. Це дасть можливість подовжити термін життя клітини зокрема i організму в цілому. Інше питання: які ж наслідки матиме втручання людини у природній хід розвитку живого. Важливим є пошук, дослідження інгібіторів та активаторів теломерази для протипухлинної терапії та ряду дегенеративних захворювань людини.

\section{Бібліографічні посилання}

Atadja, P., Wong, H., Garkavtsev, I. (1995). Increased activity of p53 in senescing fibroblasts. Proc. Natl. Acad. Sci. USA. 92(18), 8348-8352.

Baur, J.A., Zou, Y., Shay, J.W. (2001). Telomere position effect in human cells. Science. 292, 2075-2077.

Danilevskaya, O.N., Traverse, K.L., Hogan, N.C. (1999). The two Drosophila telomeric transposable elements have very different patterns of transcription. Mol. Cell. Biol. 19, 873-881.

Dynek, J.N., Smith, S. (2004). Resolution of sister telomere association is required for progression through mitosis. Science. 304, 97-100.

Harley, C., Liu, W, Blasco, M. (2011). A natural Product Telomerase Activator As Part of a Health Maintenance Program. Rejuvenation Research. 14(1), 45-56.

Jager, D., Philippsen, P. (1989). Stabilization of dicentric chromosomes in Saccharomyces cerevisiae by telomere addition to broken ends or by centromere deletion. EMBO J. 8, 247-254.

Karlseder, J., Broccoli, D., Dai, Y., Hardy, S. (1999). p53- and ATM-dependent apoptosis induced by telomeres lacking TRF2. Science. 283, 1321-1325.

Olovnikov, A.I. (1973). A theory of marginotomy: the incomplete copying of template margin in enzymatic synthesis of polynucleotides and biological significance of the phenomenon. J. Theor. Biol. 41, 181-1903.

Pardue, M.L., Rashkova, S., Casacuberta, E. (2005). Two retrotransposons maintain telomeres in Drosophila. Chromosome Res. 13, 443-453.

Rockmill, B., Roeder, G.S. (1998). Telomere-mediated chromosome pairing during meiosis in budding yeast. Genes Develop. 12, 2574-2586.

Zvereva, M.Je., Shherbakova, D.M., Doncova, O.A. (2010). Telomeraza: struktura, funkcii i puti reguljacii aktivnosti. Uspehi biologicheskoj himii. 50, 155-202 (in Russian).

Berestjanaja, A.N., Grodzinskij, D.M. (2012). Rol' telomer $\mathrm{v}$ processe kletochnogo starenija. Nauk. Visnik Uzhgorod. un-tu. (Ser. Biol.). 33, 5-16 (in Russian).

Стаття надійшла до редакиії 25.09.2016 